\title{
Na trilha dos discursos
}

RuMoRes, revista científica online dedicada aos estudos de comunicação, linguagem e mídias lança sua edição de número 12 reforçando sua reiterada tradição editorial de publicar artigos inéditos que revolvam em torno do tema da circulação discursiva nas mídias em geral e nos estudos do audiovisual como interrogação específica.

Nesta edição trazemos um dossiê composto pelos textos resultantes dos Seminários Linguagem e Práticas Midiáticas realizados por MidiATO Grupo de Estudos de Linguagem: Práticas Midiáticas (ECA-USP) durante todo o segundo semestre de 2011 na Escola de Comunicações e Artes da USP. O tema que congrega todas essas apresentações, e que agora vemos apresentado textualmente, são as desafiadoras e atuais possibilidades 
de articulação dos conceitos advindos das teorias discursivas para os problemas teóricos comunicacionais, em especial referenciados na questão dos modos de construção da representação.

O dossiê é aberto por artigo de Mayra Rodrigues Gomes situando os conceitos de discurso e de formação discursiva na teoria foucaultiana, tendo em vista aquilo que articula a fundação dos mesmos. Na perspectiva das teorias de Jacques Derrida e Jean-François Lyotard, Eliza Bachega Casadei e Rafael Duarte Oliveira Venancio tratam sobre a escritura e a desconstrução da imagem e do som analisando o filme inacabado O Inferno (1964), por meio do documentário O Inferno de Henri-Georges Clouzot (2009).

Prosseguindo na investida de pensar as particularidades do material imagético, Andrea Limberto e Rosana de Lima Soares debatem políticas da representação e a sustentação de visibilidades possíveis a partir delas, dando atenção à questão indígena. As possibilidades de construção da representação são também tema do artigo de Cíntia Liesenberg e Mariana Duccini, neste momento com a preocupação em estudar a construção de lugares sociais como forma de inscrição subjetiva e procurando observar como atua o regime ficcional nesse processo.

Mariana Tavernari e Mariane Murakami analisam, por sua vez, a representação do feminino a partir dos conceitos de dialogismo e da convergência, atentando especialmente para os novos meios e tomando como objeto os blogs de moda (fashion blogs). Os novos meios são tematizados no trabalho de Daniele Gross e Paula Paschoalick com texto apresentado em formato multimídia e tratando das políticas da representação agora associadas à perspectiva das narrativas migrantes. 
Numa sequência final de artigos do Dossiê apresenta-se a questão da fabricação de uma determinada prova de presença na realidade. E, ainda, o questionamento se tal discurso confirmador de existência influencia públicos. Felipe Polydoro trata da produção de vídeos amadores, captados por anônimos e que funcionam como provas factuais. Ivan Paganotti, através de uma análise da campanha "Não se engane", relacionada à classificação indicativa e discutindo a evidência do indesejável, analisa uma pressuposta cópia de comportamentos indesejáveis pelas crianças. E essas mesmas crianças são situadas a partir do imaginário que se constrói em torno da categoria da infância nas revistas Veja e Época, no artigo de Juliana Doretto e Renata Costa.

O corpo da edição inicia-se com dois artigos que tratam das relações entre as produções culturais em associação com as práticas institucionais e com as práticas industriais. Ana Lucia Enne investiga a relação entre cultura e política em dois momentos de atuação institucional na região da Baixada Fluminense, com as Casas de Cultura (anos 1980/1990) e com as ONGs (anos 2000/2010). Uma história do desenvolvimento da indústria fonográfica, por sua vez, é retomada por Eduardo Vicente acompanhando a mudança dos suportes e do que o autor nomeia de uma desmaterialização no meio musical.

Dos desígnios institucionais passamos a debater aqueles da figura autoral, resgatando as marcas de sua presença nos discursos. Henrique Mazetti compara os anúncios publicitários brasileiros veiculados nas décadas de 1970 e 2000 com o intuito de descobrir quais foram as transformações ocorridas nos modelos de subjetividade apresentados 
pela propaganda entre os dois períodos. Sandra Straccialano Coelho pontua teoricamente a questão da autoria no documentário por meio da análise da posição autoral do etnógrafo e cineasta Jean Rouch. Enquanto o Glauber Rocha de Deus e o diabo na terra do sol é analisado por Pedro Vaz Perez na procura por um estilo barroco americano de contraconquista.

Fechamos a edição tematizando ainda um outro tipo de desígnio, aquele da linguagem, implicado na questão dos desafios em relação a formatos: na renovação da telenovela, das mídias digitais e da mídia impressa. José Augusto Mendes Lobato trata da figuração da alteridade nas obras Duas caras, de Aguinaldo Silva, e Caminho das Índias, de Gloria Perez, distinguindo um exótico geográfico e um exótico sociocultural. Já Guilherme Ranoya analisa uma visão sobre o conceito de intuitividade com base nos autores que discutem o problema da forma dialogando com padrões, formatos e a expectativa de uma linguagem natural nas mídias digitais. Finalmente, Davys Sleman de Negreiros escrutina os editoriais da Folha de São Paulo e O Estado de São Paulo comparando-os especialmente em relação a suas agendas temáticas.

Desejamos a todos um excelente final de ano e ótimas leituras!

Rosana Soares e Andrea Limberto

dezembro de 2012 